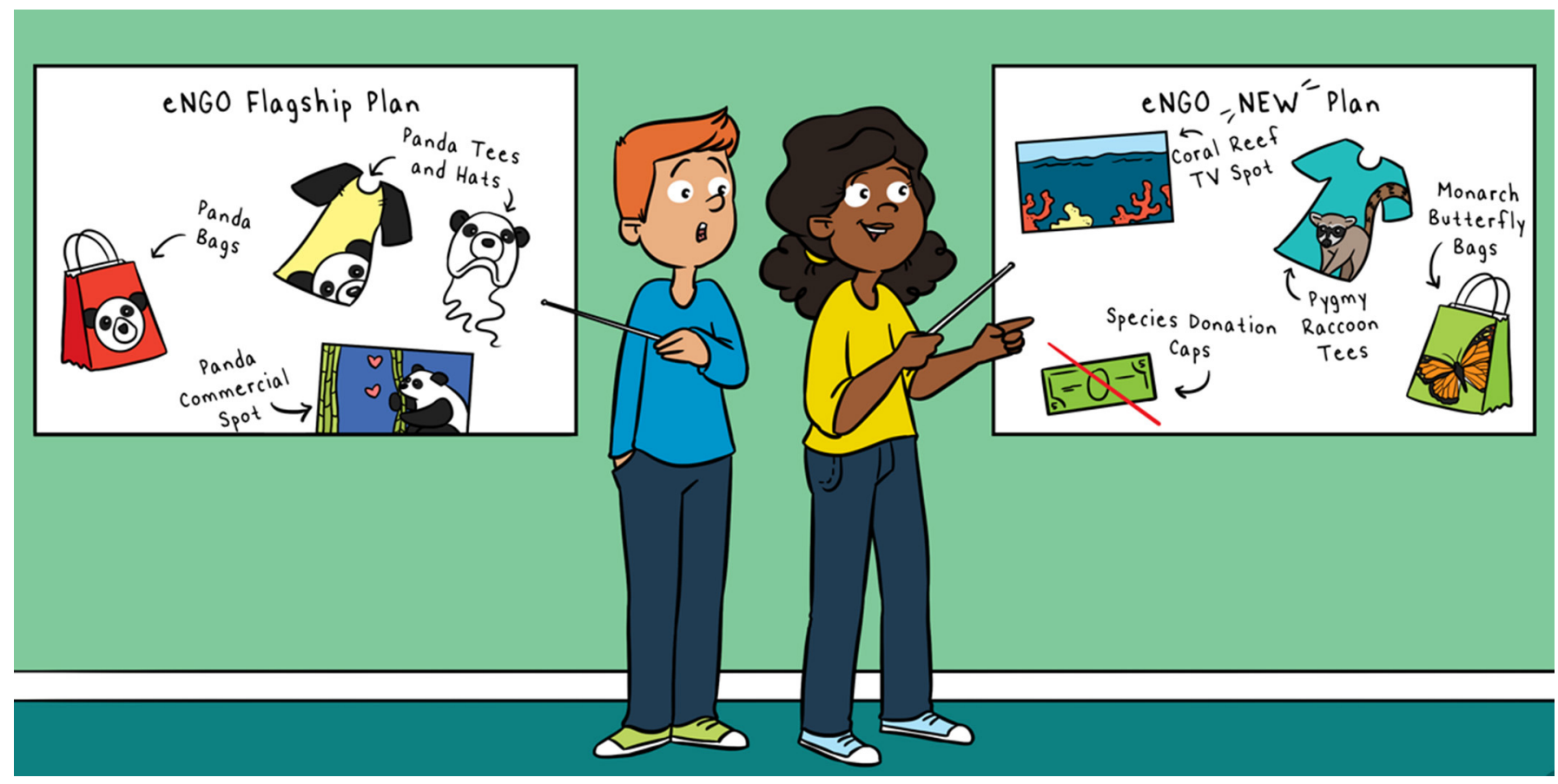

\title{
FLAGSHIP SPECIES: DO THEY HELP OR HURT CONSERVATION?
}

\section{Emily Moynes, Vishnu Prithiv Bhathe, Christina Brennan, Stephanie Ellis, Joseph R. Bennett and Sean J. Landsman*}

Institute of Environmental and Interdisciplinary Science, Carleton University, Ottawa, ON, Canada

\section{YOUNG REVIEWERS:}

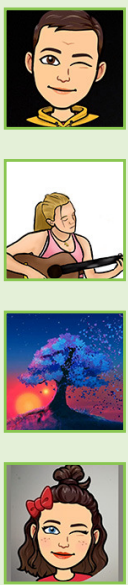

DARIO

AGE: 14

MARTA

AGE: 13

NICCOLÓ

AGE: 13

VALERIE

AGE: 13
Many of the plants and animals we love, and even more we do not know about, are in serious danger. Species extinctions are occurring at alarming rates. But how do we prevent extinction from happening? One strategy is to first make people aware of what is going on. If people know which plants and animals are in danger, they will be more likely to support measures that protect those species. We can do this by drawing attention to problems facing species that people are familiar with, like African lions, Siberian tigers, and humpback whales. Sadly, this strategy ignores many weird and wonderful creatures most people may know nothing about! More importantly, it prevents us from protecting other important species and the environments in which they live. It is time to re-think our approach so that we can protect as many species and habitats as possible! 


\section{BIODIVERSITY}

The variation of life within a given habitat or ecosystem.

ENVIRONMENTAL

NON-GOVERNMENTAL ORGANIZATION

(eNGO)

Organizations that focus on protecting specific animals, plants, and habitats, but that operate without influence from governments.

\section{CONSERVATION}

CAMPAIGN

Organized activities carried out to achieve a specific purpose related to protecting specific animals, plants, and the habitats in which they live.

\section{FLAGSHIP SPECIES}

Often large,

charismatic mammals or birds chosen by eNGOs to act as a symbol to raise public awareness and money for

conservation efforts.

\section{WHAT IS BIODIVERSITY AND WHY IS IT IMPORTANT?}

Biodiversity is the variety of life in a particular habitat or collection of habitats. A habitat's biodiversity includes everything from tiny microscopic bacteria to huge mammals like blue whales. Humans and Earth's biodiversity are closely linked. For example, the corn we eat is pollinated by bees, and many plants keep pollutants from washing into our lakes and rivers. These are just two examples of the many services that nature provides humans. Yet, human activities like large-scale construction projects and the climate change caused by human activities are causing rapid declines in biodiversity [1] .

\section{WHO PROTECTS BIODIVERSITY?}

Wildlife conservation is the act of protecting plants, animals, and the habitats in which they live. Some organizations make this their mission! We call these environmental non-governmental organizations (eNGOs). As the name suggests, these organizations are not related to the government. Many eNGOs create what are called conservation campaigns to gather money and support from the public. Such campaigns help eNGOs carry out important conservation work that protects species and the habitats they live in. But protecting all the biodiversity found on Earth is really hard! Instead, many eNGOs focus on conserving one species as a shortcut to conserving all species [2]. This one species is called a flagship species.

\section{WHAT MAKES A GOOD FLAGSHIP SPECIES?}

Flagship species are usually animals that people are familiar with. These species also have one or more appealing features. Together, these two things make some species popular symbols for conservation [3]. A common example of a flagship species is the fluffy and lovable giant panda (Figure 1). In fact, this species is used as the logo for the World Wildlife Fund. Flagship species make it easier for eNGOs to raise money because the way the animal looks makes people concerned for it and its habitat [4]. The hope is that these flagship species can be used in conservation campaigns to increase actions that lead to conservation.

Becoming a flagship species is often based on an animal's appearance. Those that are big, cute, or furry are frequently chosen [4]. These types of animals usually cause an emotional reaction in people [5]. Think about how you feel when you see a beautiful picture of a big tiger or a soaring eagle. Some studies have found that animals with large bodies, forward-facing eyes, and an overall impressive appearance make good flagship species $[5,6]$. Some eNGOs also choose large animals that have big home ranges-areas in which animals spend most of their 
Figure 1

Examples of common flagship species. (A) Giant panda (public domain CCO); (B) Benal tiger (public domain CCO); (C) Bald eagle, Photo by Lewis Hulbert/CC BY-SA 4.0;

(D) African bush elephant, Photo by Muhammad Mahdi Karim/GFDL 1.2;

(E) Mountain gorilla, Photo by Bartsouthfl/CC BY-NC 4.0.

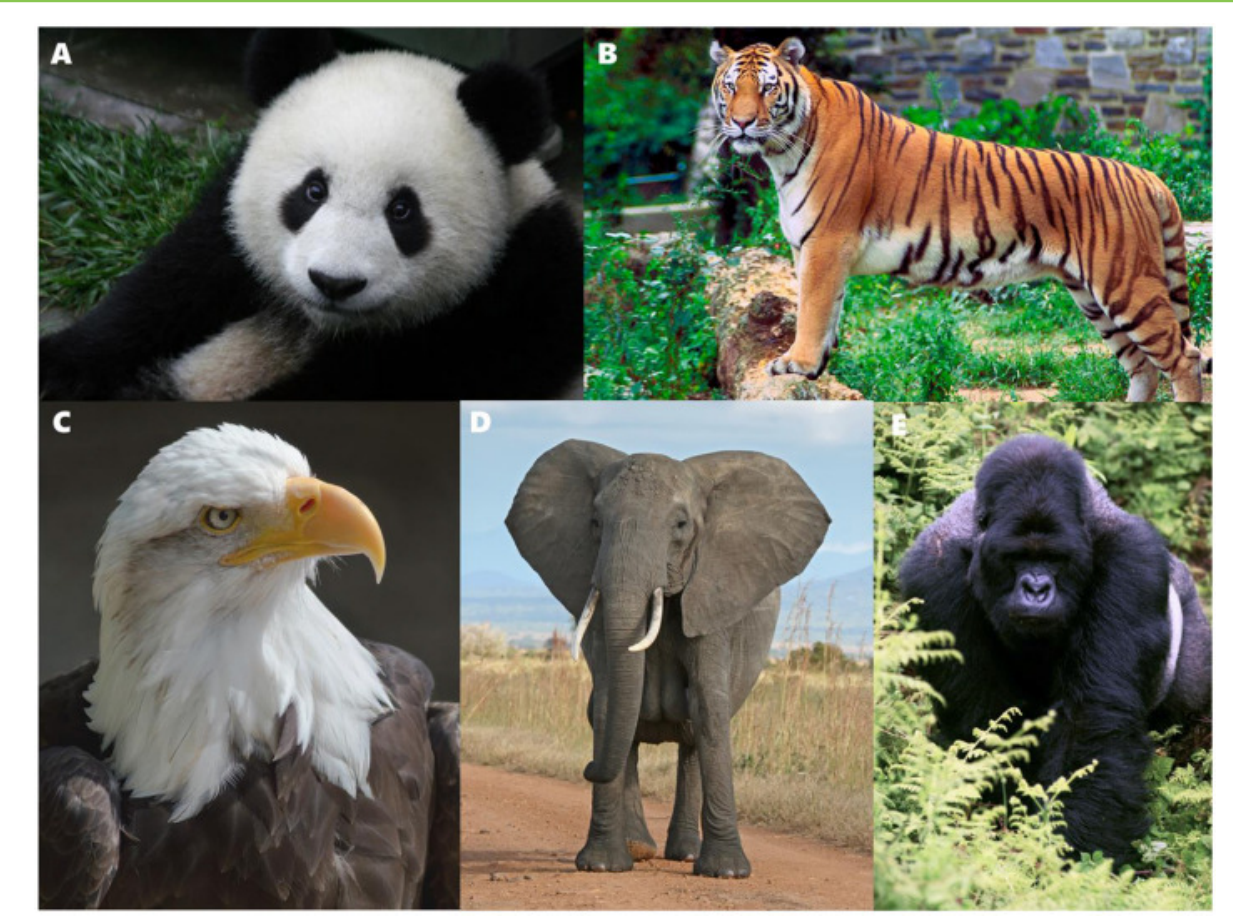

Figure 1

time-so that protection of the flagship species may also protect other species living in the same habitat [2].

\section{PROBLEMS WITH THE FLAGSHIP SPECIES APPROACH}

In reality, there are very few species that fit the typical definition of a flagship species. Choosing animals like pandas and tigers as flagship species limits the number of species that can be protected $[3,6]$. It also limits the problems an eNGO can address $[3,6]$. Not to mention that most of the money eNGOs collect for a conservation campaign focusing on one flagship species will only be spent protecting that one species [6]. This means other species will remain unprotected and at risk of extinction [8]. More careful selection of flagship species is therefore necessary [2]. Unprotected species are usually smaller, less familiar species, such as certain plants or insects. Many of these creatures were once numerous in some habitats, but are becoming increasingly threatened [7].

\section{RE-THINKING FLAGSHIP SPECIES}

Ensuring that our conservation efforts benefit large number of species is challenging. While using flagship species is one approach to protecting multiple species, we need to re-think how these species are chosen. For example, step one is to identify a particular conservation problem. This could be something like forest habitat destruction or pollution in rivers. After identifying the problem, eNGOs should 


\section{Figure 2}

Examples of Cinderella species. (A) Talaud bear cuscus, Photo by Carlosbocos/CC BY-NC 4.0; (B)

Pennant's red colobus, Photo by

Nathanelstanek/CC BY-NC 4.0; (C)

Tamaraw or Mindoro dwarf buffalo, Photo by Gregg Yan/CC BY-SA 3.0; (D) African wild ass, Photo by

Mourad-Harazallah/CC BY-NC 4.0; (E) Pygmy raccoon, Photo by Scott Camazine/CC BY-SA 3.0. Species examples from Smith et al. [6].

\section{CINDERELLA \\ SPECIES}

A species that is critically endangered and unfamiliar, but still visually appealing, and chosen by an eNGO to raise public awareness and money for conservation efforts.

\section{FLAGSHIP FLEET}

Multiple species acting as flagship species in a single

conservation campaign.

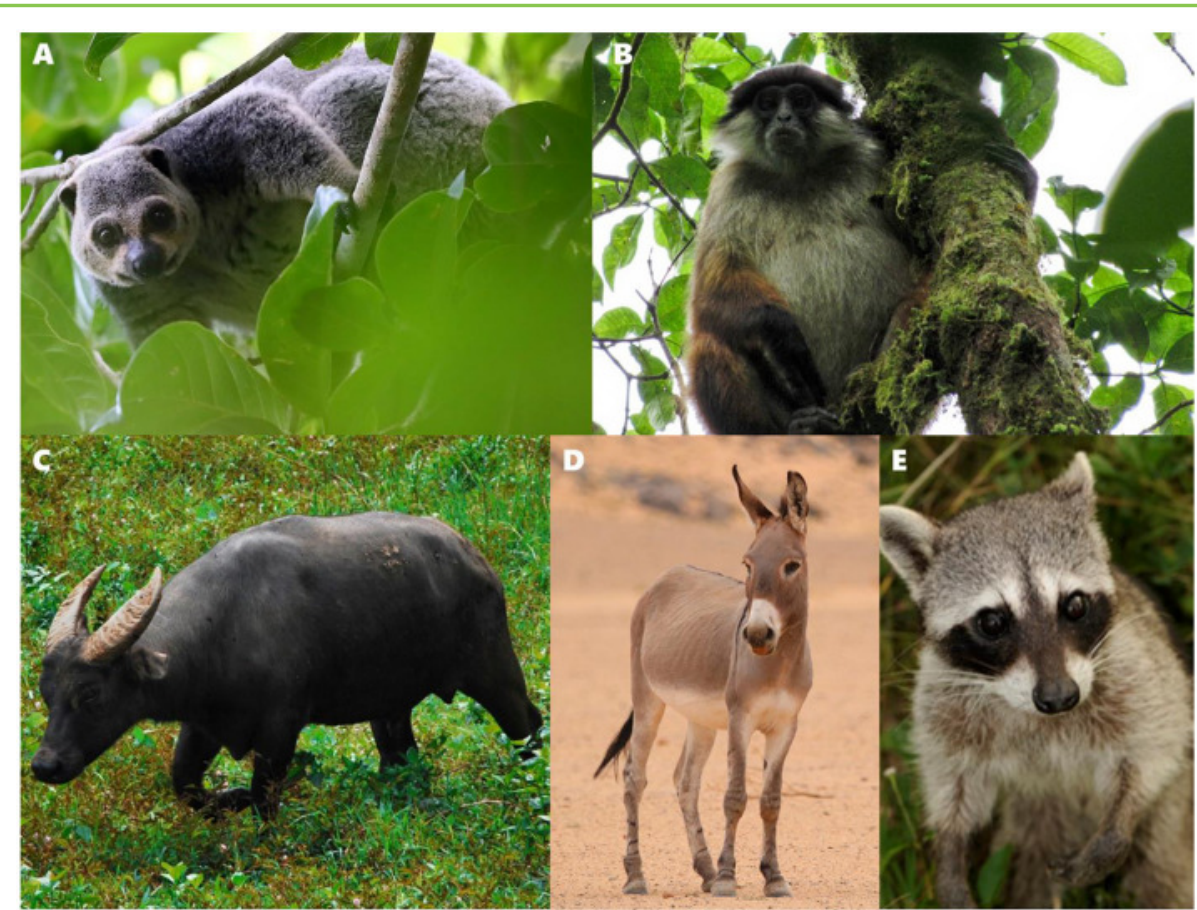

Figure 2

choose a flagship species based on who the organization is trying to appeal to [6, 9]. However, not all flagship species will remain popular forever. Some will increase in popularity and some will decline. This means that some people will become tired of reading about a once-popular species. In turn, this could lead to less support for their protection [8].

What about shifting our attention, so the focus is on less familiar species? Some conservationists think eNGOs should do just that $[2,3]$. After all, there are some truly weird and wonderful species out there! This could be a good approach, especially if some of these lesser-known species also share habitat needs with lots of other species, or if they are highly threatened [5]. Yet, people still naturally like large, cute, and furry animals! So, choosing an animal that is too bizarre may not work well. Instead, finding a species that is critically endangered and unfamiliar, but still visually appealing, is ideal [6]. These are called Cinderella species, after the tale of Cinderella, who went from being an unknown girl to a princess. You can see some examples of critically endangered Cinderella species in Figure 2.

But what if an eNGO chooses a species that some people like and others do not? This is very possible! To avoid this, some scientists think eNGOs should develop flagship fleets, or groups consisting of multiple flagship species spread across different types of animals, such as mammals and birds, for example [9]. Flagship fleets increase the chance that people will find at least one species that appeals to them, so these fleets could increase awareness of more species that need 


\section{ECOSYSTEM}

A unit of space consisting of organisms, their environment, and the interactions between them attention and, in turn, conserve more biodiversity [9]. Environmental NGOs could also set a donation limit for one particular species [3]. For instance, an eNGO might say, "We only want $\$ 100,000$ to protect lions, and any additional money we receive will go to protect other plants, animals, and habitats." This supports the idea that the ideal flagship species helps protect other forms of biodiversity [4].

What about moving away from single species and building conservation campaigns that protect entire ecosystems instead [3]? For instance, coral reefs and tropical rainforests are two of the most diverse ecosystems on Earth! Or conservation campaigns could focus on specific areas as opposed to species, such as national parks [3]. There are also some examples of single species that could act as flagships for entire ecosystems, such as the golden lion tamarin representing the Atlantic rain forest, or for entire groups of animals, like the monarch butterfly representing insects [7, 10]. These approaches shift the focus to benefit a wider range of biodiversity through the conservation of more species and habitats.

\section{CONCLUSION}

Flagship species like tigers and pandas are frequently used by eNGOs to increase awareness and raise money for conservation initiatives [6]. And yet, a single-species approach that favors mammals and birds has been criticized. Conserving as much biodiversity as possible should be the main goal of any conservation campaign. So, eNGOs could choose different flagship species, direct extra money from flagship species funds to other projects, add more species to create a flagship fleet, or campaign for ecosystems or whole animal and plant groups $[2,3,6,9]$. Any of these solutions, including combinations of them, may prove beneficial. Earth has so much wonderful biodiversity that is worthy of our protection!

\section{REFERENCES}

1. Pimm, S. L., Jenkins, C. N., Abell, R., Brooks, T. M., Gittleman, J. L., Joppa, L. N., et al. 2014. The biodiversity of species and their rates of extinction, distribution, and protection. Science 344:1246752. doi: 10.1126/science.1246752

2. Simberloff, D. 1998. Flagships, umbrellas, and keystones: is single-species management passé in the landscape era? Biol. Conserv. 83:247-57. doi: 10.1016/s0006-3207(97)00081-5

3. Verissimo, D., MacMillan, D. C., and Smith, R. J. 2011. Toward a systematic approach for identifying conservation flagships. Conserv. Lett. 4:1-8. doi: 10.1111/j.1755-263X.2010.00151.x

4. Walpole, M. J., and Leader-Williams, N. 2002. Tourism and flagship species in conservation. Biodivers. Conserv. 11:543-7. doi: 10.1023/A:10148647 08777 
5. Clucas, B., Mchugh, K., and Caro, T. 2008. Flagship species on covers of US conservation and nature magazines. Biodivers. Conserv. 17:1517-28. doi: 10.1007/s10531-008-9361-0

6. Smith, R. J., Verissimo, D., Isaac, N. J., and Jones, K. E. 2012. Identifying Cinderella species: Uncovering mammals with conservation flagship appeal. Conserv. Lett. 5:205-12. doi: 10.1111/j.1755-263x.2012.00229.x

7. Dietz J. M., Dietz L. A., and Nagagata E. Y. 1994. "The effective use of flagship species for conservation of biodiversity: the example of lion tamarins in Brazil," in Creative Conservation: Interactive Management of Wild and Captive Animals, eds P. J. S. Olney, G. M. Mace, and A. T. C. Feistner (Dordrecht: Springer). p. 32-49.

8. Entwistle, A. 2000. Flagships for the future? Oryx 34:239-40. doi: 10.1017/S003060530003129X

9. Veríssimo, D., Pongiluppi, T., Santos, M. C. M., Develey, P. F., Fraser, I., Smith, R. J., et al. 2013. Using a systematic approach to select flagship species for bird conservation. Conserv. Biol. 28:269-77. doi: 10.1111/cobi.12142

10. Guiney, M. S., and Oberhauser K. S. 2009. Insects as flagship conservation species. Terr. Arthropod. Rev. 1:111-23. doi: 10.1163/187498308X414733

SUBMITTED: 25 June 2020; ACCEPTED: 21 May 2021;

PUBLISHED ONLINE: 21 June 2021.

EDITED BY: Didone Frigerio, University of Vienna, Austria

CITATION: Moynes E, Bhathe VP, Brennan C, Ellis S, Bennett JR and Landsman SJ (2021) Flagship Species: Do They Help or Hurt Conservation? Front. Young Minds 9:576035. doi: 10.3389/frym.2021.576035

CONFLICT OF INTEREST: The authors declare that the research was conducted in the absence of any commercial or financial relationships that could be construed as a potential conflict of interest.

COPYRIGHT @ 2021 Moynes, Bhathe, Brennan, Ellis, Bennett and Landsman. This is an open-access article distributed under the terms of the Creative Commons Attribution License (CC BY). The use, distribution or reproduction in other forums is permitted, provided the original author(s) and the copyright owner(s) are credited and that the original publication in this journal is cited, in accordance with accepted academic practice. No use, distribution or reproduction is permitted which does not comply with these terms.

\section{YOUNG REVIEWERS}

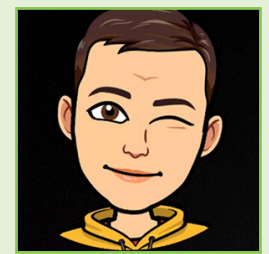

\section{DARIO, AGE: 14}

My name is Dario. I live in a small village in Austria. It is full of nature so in my freetime I like to go out with my dogs or climb trees. My parents are both biologist so I got into biology pretty early. 

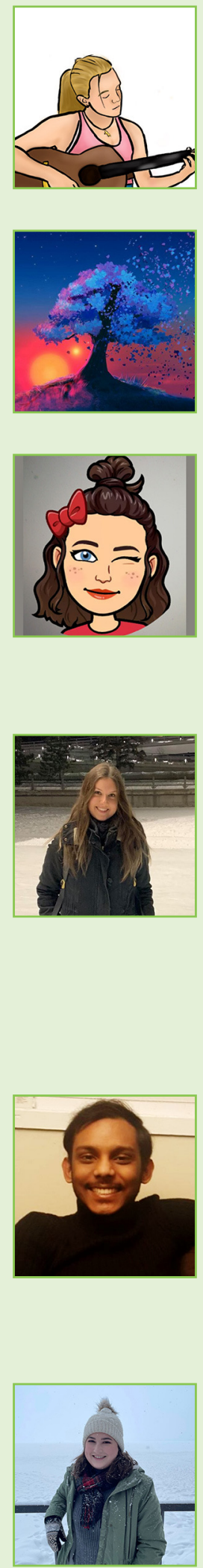

\section{MARTA, AGE: 13}

I am an eighth-grade student, currently studying at an international school where I discovered my love for science and creative writing. My passion for horses has further sparked my interest in biology, inspiring me to push myself so I might 1 day find out all there is to know about both plants and animals.

\section{NICCOLÓ, AGE: 13}

My name is Niccoló, I am in the eighth grade with a strong love for "social psychology," I enjoy story writing and cannot live without music. I have lived in several different countries and gone to many different schools. I have a brother at the age of 12 and we share very diverse interests.

\section{VALERIE, AGE: 13}

I am in eighth grade of a middle school in Austria. My hobbies are horseback riding, skating, and dancing. I have got a very old cat and we are getting a dog soon. I also like meeting my friends and listening to some music.

\section{AUTHORS}

\section{EMILY MOYNES}

Emily is a fifth-year undergraduate student studying Environmental Science at Carleton University in Ottawa, Ontario, Canada. During her schooling, she completed an internship under the supervision of Dr. Steven Cooke on various fish-related projects, resulting in a publication in Transactions of the American Fisheries Society. She is currently completing her honors thesis with Dr. Thomas Sherratt on insect body toughness. She loves acquiring new knowledge and experiences in her field and hopes to 1 day obtain a job exploring animal behavior or working toward conservation-related initiatives.

\section{VISHNU PRITHIV BHATHE}

Vishnu Bhathe recently graduated from Carleton University in Ottawa, Ontario, Canada with a Bachelor of Science degree. Ever since he was a child, he has been curious about science and how people use the lessons from science to better the world. He is also interested in entrepreneurship and aims to use scientific research to fuel innovation. In his free time, he likes to ride bikes, paint, read books, and exploring new things.

\section{CHRISTINA BRENNAN}

Christina Brennan is an undergraduate student at Carleton University in Ottawa, Ontario, Canada majoring in interdisciplinary science. She is especially interested in pursuing a career in science communication, and using the skills developed in her undergrad to bridge the gap between disciplines. Since she was 10 years old, Christina has been designing floor plans of houses on graph paper and continues to do so today through 3D modeling. Aside from her academic goals, she hopes to 1 day design and build her own net zero home. 

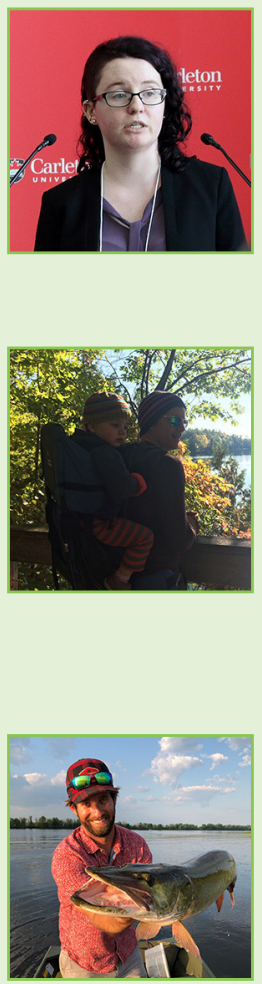

\section{STEPHANIE ELLIS}

Stephanie is an undergraduate student in her final year of the Interdisciplinary Science and Practice program in Ottawa, Ontario, Canada. She is passionate about community engagement and figuring out how different systems work, from the human brain to computers. She was inspired by her teachers to continue searching for answers and to follow her passions at a young age.

\section{JOSEPH R. BENNETT}

Joe is an Associate Professor at the Institute of Environmental and Interdisciplinary Sciences and Department of Biology at Carleton University. Research in his lab focuses on saving species from extinction, and preventing invasive species from damaging ecosystems. He grew up in Ontario, on a farm that was surrounded by forests and wetlands. He is always loved nature, and now devotes his research to helping take care of it.

\section{SEAN J. LANDSMAN}

Sean is a teaching professor in the Interdisciplinary Science and Practice program at Carleton University in Ottawa, Ontario, Canada on the unceded territory of the Algonquin First Nation. He is a trained fisheries ecologist and studies how fish move about their environments as well as how people affect them. He is also a passionate science communicator and enjoys sharing his knowledge with anyone that will listen! In fact, it was this love of communicating fisheries science that led him to photography and specifically http://seanlandsmanphotography . com/underwaterphotography. Sean loves to spend time outdoors, especially fishing and hiking, and enjoys tinkering in his basement making things out of wood. *sean.landsmanacarleton.ca 